\title{
REFLECTING OURSELVES
}

\section{'Maoriland' in the Mirror}

\author{
STEPHEN HAMILTON
}

$\mathrm{P}$

UBLISHED IN AUCKLAND as a national monthly magazine between 1922 and 1963, the Mirror was the first serious attempt to compete locally with imported quality magazines. Titled the Ladies' Mirror: The Fashionable Ladies' Journal of New Zealand, it initially directed itself towards a middle-class female readership. Photographs were always an important component of its contents, with issues published during the 1920 s opening with up to ten pages of society portraits, including the current crop of debutantes and frontispiece photographs of members of the establishment, the Governor-General or Prime Minister, or perhaps their wives. Certainly, women were the overwhelming subject for these photo spreads, a preoccupation sustained in the selection of images of Māori, though there were other contributing factors in this latter selection, factors I will explore in the course of this article.

Circulation of the Mirror grew rapidly through its first year to sustain a remarkable average of 10,000 copies per issue over the forty years of its publication. Sales peaked at 25,000 copies with the Christmas edition for 1924, an issue which signalled that the Mirror was established as the premier monthly in the Dominion. Its cover and over 30 pages were produced with the newly imported four-colour printing process offered by Whitcombe \& Tombs using colour plates prepared by Auckland Photo Engravers.

In order to compete with imported British, American and Australian magazines, the Mirror increasingly emphasised the local and indigenous in its content, following the lead of more established periodicals such as the Weekly News.

Photographs were an important component of this shift, with their subject matter covering the entire range typically treated by the pictorial press, from royal tours and society weddings, to New Zealand scenery and Māori culture.

A major force behind the ability of the magazine to adapt to the needs and expectations of its changing readership was its main owner and Managing Director, Henry Kelliher. While he did not set up the Mirror, Kelliher acquired it in partnership with Alexander Geddes in late 1923. Even prior to the death of Geddes in
1936, Kelliher was the personality most closely associated with the magazine. In the mid 1920s he was already emerging as a prominent Auckland businessman and over the next few decades appeared increasingly to style himself on the brewing and press barons of Great Britain. Kelliher's business career began with the purchase of a hotel in the Wairarapa in 1917. Subsequently, he formed an importing and exporting business in Auckland winning a lucrative contract to distribute Dewar's whiskey in New Zealand. His interests in the liquor industry grew throughout the 1920 s, culminating in his founding of Dominion Breweries in 1930. ${ }^{1}$

Apart from its primary role as a profit making venture, Kelliher used the Mirror to promote social innovations such as the provision of milk in primary schools, championed in coordination with the League of Health for New Zealand Youth, another of his initiatives. He also argued in the magazine for radical reform of the monetary system. Articles by Kelliher on this subject were later gathered into his multiple edition New Zealand at the Cross- 
Roads, first published in the same year as his appointment as a Director of the Bank of New Zealand. ${ }^{2}$ Kelliher also took up the role of patron of the arts, supporting local painting through an annual landscape art competition which ran for 27 years between 1956 and 1983 .

Before proceeding to discussion of the images, I'd like to take the opportunity to locate myself in the study by making a plea for subjectivity. There is, I feel, a need to address the obvious problematic of writing across cultural boundaries: I am a Pākehā New Zealander, born in Leith on the Firth of Forth, of Lowland Scottish Border stock. My mother is a Stuart, my father a Hamilton, and, although I haven't gone beyond my immediate forbears, it would seem likely that my ancestors survived successive and violent colonisations by the English. Our immigration to New Zealand in the mid sixties may be read as one further hopeful move out of the path of economic and political dislocation. I will be ever grateful that my parents had the prescience to remove us from the gloom of north-west England. This personal story gives me no authority in the matters I'm about to discuss, but it may explain my fascination with the discourses and effects of colonialism.

I would also like to address one or two other issues which for me problematise any re-presentation of images from the past. There is a danger that in showing these images of Mãori and discussing the way in which they are presented in the Mirror I will simply re-inscribe them, rehearsing 70 years later the same discourse they voiced in the 1920 s. It is clearly not sufficient to say, 'look how Māori were represented in 1926'. What is required is an analysis of the images to reveal their essentially political function in the prevailing hegemony of late colonial New Zealand. My argument is founded on my belief that in publishing these highly circumscribed representations of Māori, and in particular of Te Arawa, the Mirror contributed to an effective erasure from the consciousness (and conscience) of mainstream middle-class Pākehā of the complex reality of Mãori in late colonial New Zealand.

Finally, I must stress that I intend to treat the photographs with as much respect as possible in this setting. Although not framed and mounted on the wall of whare nui or private homes, they must nevertheless be regarded as taonga, as they are representations of real individuals, tupuna of people living today. So often in the Mirror and elsewhere these individuals are merely presented as stereotypes, as 'Maori maidens' or 'Types of Maori motherhood'. Although numerous photographs of Pākehā were also captioned in similar ways, the political import differs. It is this anonymity and stereotyping which I mean to work against. Indeed, the best possible response to this article would be a cry of recognition.

Regarding my specific subject matter, I hope to construct a narrative around the photographs, keeping in mind Ron Burnett's comment in his Cultures of Vision that 'narratives can be generated from any picture; intentionality finds its place, not so much in the authority of the images, but in the imaginary dialogues we establish with them'. ${ }^{3}$ The dialogue I have derived in this case is centred on the suggestion that the treatment in these photographs of Mãori as ethnological subjects worked to nullify their otherwise problematical presence in late colonial New Zealand society, a presence characterised by rural poverty, alienation from the ancestral lands and the beginnings of a drift towards the urban centres in search of work. I will argue that, in effect, the photographs in the Mirror and similar magazines during the interwar period effectively rendered Māori invisible by displaying them exclusively as iconographic symbols of a past and, by implication, passing if not dying, culture. I should qualify this generalisation by the acknowledgment that most of the photographs we will view are of Te Arawa tupuna, members of a tribe which adapted better than most to the appearance of large numbers of Europeans in their area, specifically by serving the needs of visitors to the 'thermal wonderland' of Rotorua.

Some comment on the special significance of photographs in Mãori culture will provide further context for my discussion. In a short piece in the journal Photofile in 1988, Wiremu Cooper describes the way in which photographs came to be appropriated by Māori in whakapapa and the rituals associated with the death. Missionary discouragement of carved ancestor figures and the addressing of these during orations - which they regarded as a form of idolatry - led from as early as the late 1850 s to the custom of hanging photographs in meeting houses. Today photographs are commonly used at tangi and other rituals and are addressed in orations. 


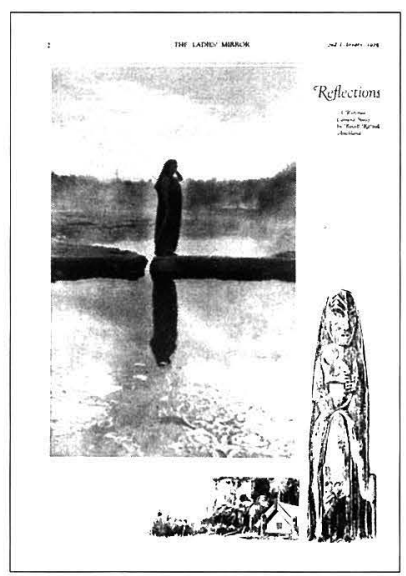

Illustration 1: Revell Reynolds, 'Reflections', Mirror, February 1925, 2. Alexander Turnbull Library Serials Collection, S-L 159-2.

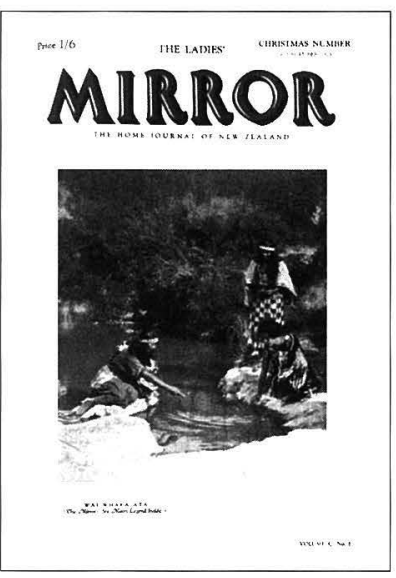

Illustration 2: 'Wai-whaka-ata', Mirror, December 1925, cover. Alexander Turnbull Library Serials Collection, $S-L$ 109-COVER-B.
Cooper points out that ' $[\mathrm{i}] \mathrm{n}$ many areas this custom has superseded the practice of placing valuable ornaments, weapons, and other highly regarded personal possessions, around the deceased person's body'. ${ }^{4}$ Clearly, we have here one instance among many of the speed with which Māori adapted the things of the Pākehā into their own systems of signification. One only has to conjure the image of recent tangi of eminent kaumātua and kuia broadcast on New Zealand television to realise that photographic portraiture has obtained a depth of meaning for Māori beyond that commonly ascribed to the medium by Europeans.

Turning now to the first image (Illustration 1), from the issue for February 1925, this is one of the earliest photographs of its type in the Mirror. It is typical of the romantic renderings of Te Arawa popularised since the turn of the century by Rotorua photographers such as George Isles. Titled 'Reflections' (thus linking it to the title of the magazine) it is attributed to Revell Reynolds of Auckland. The part framing of the photograph by drawings of an elaborate gateway and whare, provide a focus for the pensive reflections of the lonely subject - reflecting perhaps on the lost glories of her culture, or even on its predicted demise, a belief about Māori as a 'dying race' being still current at the time.

For Pākehā New Zealand, and hence the readers of the Mirror, Māori women were most often linked to images of Rotorua, largely because of their roles as guides. As Ngahuia Te Awekotuku points out in her essay 'Kai Arahi: Women and Tourism',
'Tour guiding had become an almost exclusively female profession', partly owing to the monopolisation of male labour by the forestry industry from 1898 and partly as an extension of the traditional female roles of welcoming and entertaining visitors, puhi and kai ārahi. There was also the added benefit of at least a seasonal supplementary income. ${ }^{5}$ I will refrain from commenting further on the role of Mãori women in tourism, and merely refer you to Te Awekotuku's Mana Wahine Maori, and her PhD thesis 'The Sociocultural impact of tourism on the Te Arawa people of Rotorua'. ${ }^{6}$

Rotorua guides were almost certainly employed as models in the second photograph (Illustration 2), the cover page of the issue for December 1925, illustrating an article by Sir Peter Te Rangi Hiroa Buck entitled 'Wai-Whaka-Ata - The Maori Mirror'. Active in the Polynesian Society, as an ethnologist Buck was particularly concerned with the material culture of Mãori and other Pacific peoples. His monograph on The Evolution of Maori Clothing appeared in 1926 and he went on to describe Pacific cultures in several popular books, including Vikings of the Sunrise. ${ }^{\text {? }}$

The article by Buck gives a brief account of the use of still pools as mirrors and as divining pools by what he terms 'neolithic Maori'. He notes that named pools such as Te Wai Whaka-Ata o Ihenga near Ohinemutu at Rotorua have been cited in the Native Land Court and goes on to suggest that, 'Maori have been influenced by European ideas. The maidens gazing in the ancient reflecting pool are looking for other reflections than their own'. By 


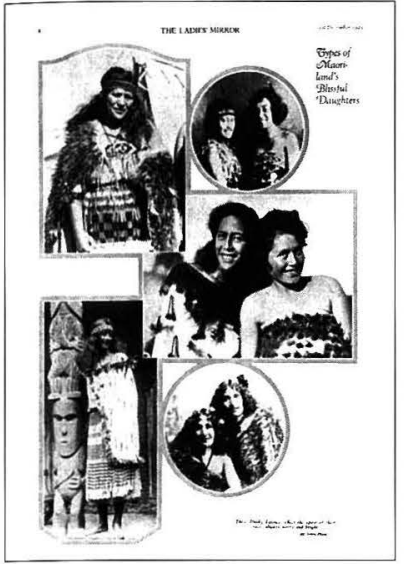

Illustration 3: Alf. Jones, 'Types of Maoriland's Blissful Daughters', Mirror, December 1925, 4. Alexander Tumbull Library Serials Collection, S-L 109-4-A.

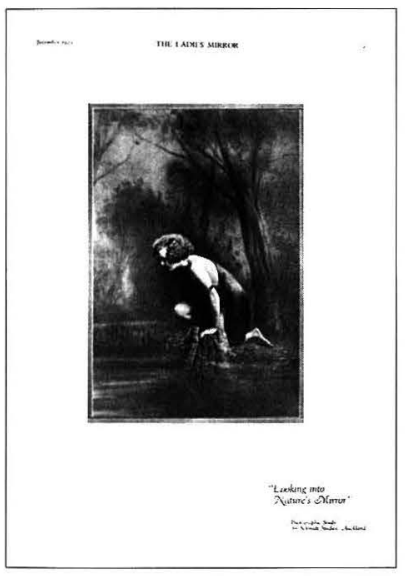

Illustration 4: Schmidt Studios, 'Looking into Nature's Mirror', Mirror, December 1925, 7. Alexander Turnbull Library Serials Collection, S-L 109-7 -A. disturbing the water with a pebble, it is hoped that the resulting ripples will reveal the face of their future husband. There may be a Celtic source for this use of reflecting pools in divination, though it should also be noted that in classical times to disturb the image in water was regarded as profoundly threatening to the soul. What is of interest here, especially in the light of Buck's well known assimilationist views, is his description of the modifying by Māori of their own traditions by the adoption of European ideas, one of many examples of what Mary Louise Pratt describes as 'transculturation', an ethnographic term for the adaptation of aspects of the metropolitan culture by colonised peoples. $^{8}$

Buck's article is given some context in the Mirror by a spread of photographs on the facing page (Illustration 3), presumably of Mãori women who have been employing their local pools in their more profane usage. Titled 'Types of Maoriland's Blissful Daughters', it has the additional caption 'These Dusky Lassies reflect the spirit of their race always merry and bright'. The photographs appear to have been made over an extended period and probably by more than one photographer, despite their being collectively attributed to Alfred Jones. Jones contributed regularly to the Mirror over the inter-war period. He appears to have been active in Rotorua from at least the mid teens of this century, and may have taken up some of the work of George Isles who seems to have retired by about 1920 . With their smiling subjects unnamed, presented as mere 'types', the primary narrative of these photographs differs little from that derived from earlier ethnological photographs in which the image is presented as, to borrow the terminology of Roland Barthes, a 'certificate of presence... literally an emanation of the referent'. The referent in this case is a version or aspect of traditional Māori society, a representation of the role of women in welcoming the visitor, the puhi and kai ărahi roles previously mentioned. The 'graven deity' in the lower left photo adds further authenticity to the traditional costumes. However, we should also be aware that, as was often the case, the surface documentary, ethnographic and decorative impulse merges subtly with the voyeuristic: bare shoulders, open smiles, perhaps the promise of a freer sexuality than that enjoyed by the sons of a Victorian immigrant culture.

Somewhat less ambiguously voyeuristic, Illustration 4 appeared in the same issue, two pages after the Buck article. It forms a curious counterpoint to the cover page image of the Mãori 'maidens' employing the still pool as a mirror (Illustration 2). Attributed to Schmidt Studios of Auckland, this carefully contrived study seems to suggest a classical heritage for Mirror readers. Narcissus springs to mind, gazing into Echo's pool, though feminised. Perhaps she's looking into a magic pool for the face of her suitor, as suggested by Buck. The painted backdrop shifts the photo towards a reconstruction of a painting, a popular genre in photography at the time. Romantic renderings of classical scenes by members of the Pre-Raphaelite Brotherhood come to mind. The mistiness of the image enhances the romantic 


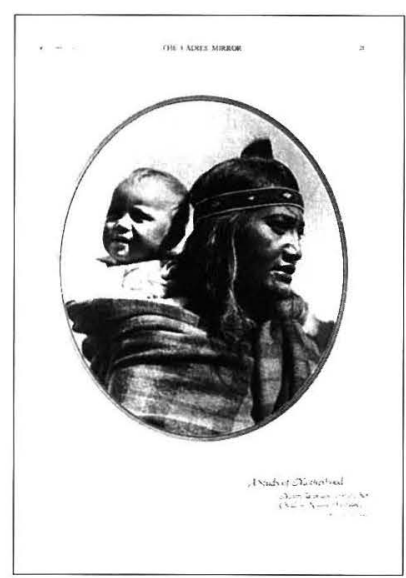

Illustration 5: Alf. Jones, 'A Study of Motherhood', Mirror, December 1925, 21. Alexander Turnbull Library Serials Collection, S-L 109-21 -A.

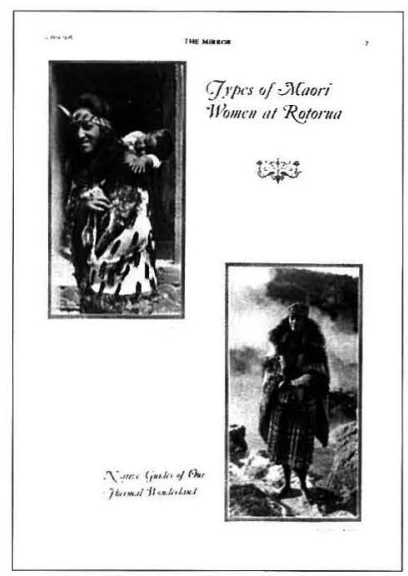

Illustration 6: C. Troughton Clark, 'Types of Maori Wonen at Rotorua', Mirror, April 1926, 7. Alexander Turnbull Library Serials Collection, S-L 110-7-A. element, while the strategically draped garment adds a subtext of subtle voyeurism.

Also in the same issue is this 'Study of Motherhood' by Alfred Jones, captioned 'Maori Woman carrying her child in native fashion' (Illustration 5). This particular image was used several times in the Mirror through the twenties and thirties, while the use of other mother and child photographs indicate their popularity, appropriate for a woman's magazine. The problem, again, is in the lack of naming, the stereotyping of the figure. Readers are encouraged to construct a positive narrative of maternal caring, infant health, and, in the light of it being the December issue, it may also be read as a representation of an indigenous Madonna and Child.

Another version of the same image appeared the following April, here placed in front of a carved doorway (Illustration 6). The accompanying photograph shows a woman, probably a guide, amid the 'thermal wonderland' of Rotorua. Again Te Arawa women are shown in traditional costume in what were regarded as typical settings. These same photographs may well also have been reproduced as images on postcards, as souvenirs of visits to Rotorua. They also act to promote Rotorua to Mirror readers.

I should note here that tourism within New Zealand was developing rapidly in the 1920s, bolstered by improvements to the roading system which allowed easier access to places such as Rotorua and the central North Island from both Auckland and Wellington. Numerous magazine articles and publications such as
Whitcombe and Tombs' Maori Life in New Zealand and New Zealand in Pictures $^{9}$ and James Cowan's landmark two-volume Travel in New Zealand ${ }^{10}$ encouraged New Zealanders to explore their country and discover just what it was that made it unique. From September 1924 the Mirror itself promoted travel with a regular and long running motoring column, directed towards women drivers and well worth study in its own right as a contribution to the promotion of 'Maoriland' in the minds of New Zealanders.

The caption for Illustration 7, 'Bewitching Maori Guides at Rotorua', has the subtitle 'Preparing for a Royal Reception', a reference to the 1927 visit of the Duke and Duchess of York, the future King George VI and Queen Elizabeth, the present Queen Mother. Being a loyal British as well as a New Zealand magazine, this and subsequent royal tours featured heavily in the Mirror. Photographed by the New Era Co. of Auckland, these particular guides have apparently progressed beyond still pools to the ownership of hand mirrors, one of numerous self-referential uses of mirrors in Illustrations in the Mirror. However, having had his subjects attend to their appearance in the upper and middle photographs, the photographer introduces a nice circularity into the third, putting a camera into the hands of one of the guides, while her companions pose.

Interest in the Royal Visit peaked with the issue for February 1927, which featured a double page photo spread. On the left hand page appeared Illustration 8 , an impressive portrait captioned 'Rangatira nui o Te Arawa', complete with traditional 


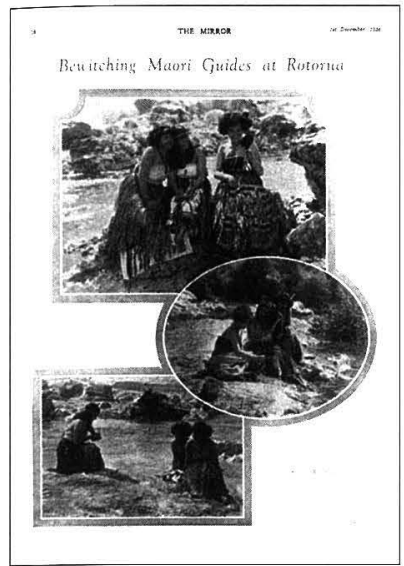

Illustration 7: New Era Co, 'Bewitching Maori Guides at Rotorua', Mirror,

December 1926, 18. Alexander Turnbull Library Serials Collection, S-L 111-18-A.

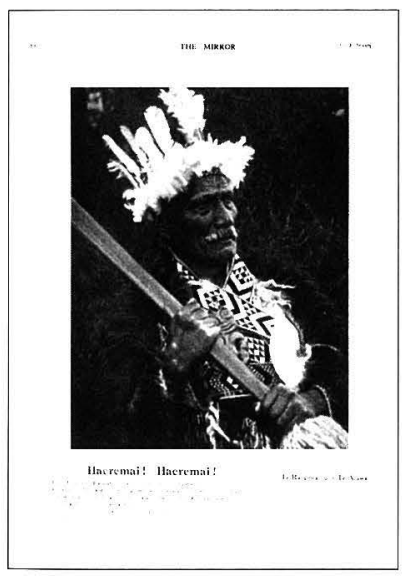

Illustration 8: 'Haeremai! Haeremai!', Mirror, February 1927, 10. Alexander Turnbull Library Serials Collection, S-L 112-10-A. greeting to the Duke and Duchess of Wales, formal photographs of which appeared opposite. The rangatira is Mita Taupopoki, the most senior and well known Tuhourangi and Ngati Wahiao leader of his generation. Decorated for service with the Te Arawa contingent in the wars of the 1860s, he repeatedly and with some success represented his hapu in the Native Land Court through the 1880s. He toured the United States with Guide Maggie Papakura's cultural group in 1910 and would have taken a major role in hosting the Royal visit to Whakarewarewa in 1927. A willing subject for photographers, he was known for his elaborate head-dress and noble appearance. Goldie painted his portrait in 1933, two years before his death at the age of about ninety. ${ }^{11}$

In this portrait of what would have been regarded as an exemplary 'old-time Maori', Mita Taupopoki represented to readers of the Mirror an indigenous aristocracy, loyally British yet uniquely New Zealand. He faces the Royal couple on the opposite page, in full ceremonial dress, wielding his taiaha and with the words of greeting printed below, with 'Translation on Page Six'. More significantly, and keeping in mind the known complicity of this particular subject in the process of photography, the image raises questions of signification beyond those of the Māori women we have already seen. If 'ethnographic texts are the means by which Europeans represent to themselves their (usually subjugated) others', then, borrowing from Mary Louise Pratt, we might describe what Mita Taupopoki is doing here as 'autoethnologizing', whereby 'colonized subjects undertake to represent themselves in ways that engage with the coloniser's own terms', a process that involves 'partial collaboration with and appropriation of the idioms' of the coloniser. ${ }^{12}$ Mita has appropriated the idiom of photography and employed, some would say excessively, the traditional codes of status (for example, the white feathers of his head-dress) to satisfy the needs of the coloniser for authenticity.

As Pratt also asserts, and as is confirmed by the context of this photo, '[a]utoethnological texts are. - usually addressed both to metropolitan readers and to literate sections of the speaker's own group' ${ }^{13}$ Regarding the former 'listeners', Taupopoki speaks directly to the Royal couple and all they represent. His photograph is orientated so that he faces them directly and he greets them with the waiata of welcome reproduced below his image. Pākehā readers of the magazine occupy a position midway between the metropolitan and the colonised, being British and approving the expression of loyalty able to be read in the montage of text and image, and also being New Zealanders, proud inhabitants of 'Maoriland', on whose behalf Mita Taupopoki is speaking. What we have here is one instance among many of New Zealand / 'Maoriland' representing itself to the metropolitan centre, fully exploiting the elaborateness of traditional culture. Moreover, the racial 'full-bloodedness' of Mita Taupopoki encourages the reader to applaud his otherness, a sort of invert racism, celebrating his explicit difference from the Royals, a difference safely contained by the context. 


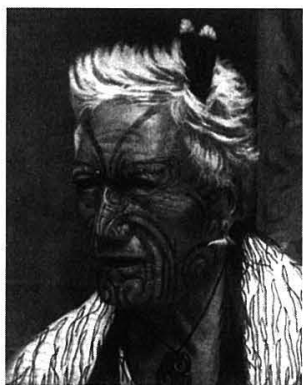

Maori Character Studies (After Goldie)

\section{Hudson's Chocolates}

Illustration 9: 'Maori Character Study (After Goldie)', Mirror, December 1931, 5. Alexander Turnbull Library Serials Collection, S-L 113-5 -A.

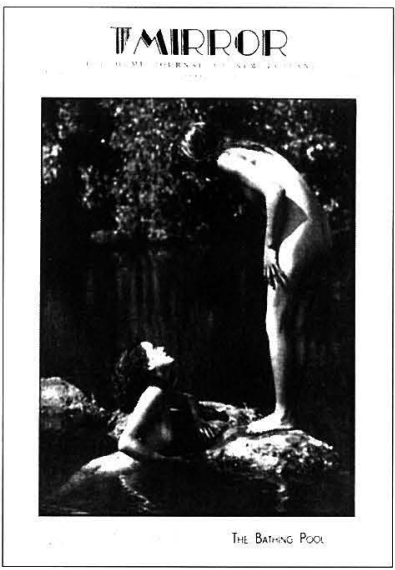

Illustration 10: A. A. Hintz, 'The Bathing Pool', Mirror, April 1934, cover. Alexander Turnbull Library Serials Collection, S-L 114-TITLE-B.
Any threat which might be read in the fierceness of his expression or firmness of his grip on the taiaha is defused by the easily understood title of the waiata: 'Haeremai! Haeremai!'

I can only speculate on the reception these photographs may have had among Te Arawa at the time, but suspect it would have been one of overwhelming approval, not to say pride. Mita Taupopoki is after all greeting the grandchildren of Kuini Wikitōria, the face of the Treaty partner, to whom Te Arawa remained loyal through all the disturbances since 1840 .

To change tack slightly, Illustration 9, from December 1931, is a typically insensitive example of the widespread appropriation of images of Māori for commercial use. The Ephemera collection at the Alexander Turnbull Library has numerous such images, some of which may be seen on the Library's web site, Timeframes (http://timeframes.natlib.govt.nz/). The advertisers in this case are offering a series of reproductions of 'Maori Character Studies (After Goldie)', decorating boxes of chocolates. The reproductions are described as being 'true to type and correct in detail', satisfying the urge for ethnographic authenticity. They are promoted as being easily detached for framing, and the whole package is directed towards the Christmas market 'for presentation to visitors and tourists'. The advertisers and all concerned were doubtless unaware of the offensive juxtaposition of the tapu image of the individual, particularly the head, and the noa or profane nature of foodstuffs.

By the mid 1930s, the Mirror had completed the transition from a
'Ladies' magazine ostensibly directed towards the haute bourgeoisie, if such a class can be said to have existed in New Zealand, to a more general readership, competing with a whole range of other local magazines founded in the late 1920s and early 1930s, including the New Zealand Women's Weekly (1932-), the New Zealand Railways Magazine (19281940) and the Christchurch based Home Journal (1934-1974). Dated April 1934 and attributed to the photographer A.A. Hintz, Illustration 10 is a remarkable late example of the appeal to voyeurism in photographs of Mãori more commonly seen in the late 19th century. Tastelessly exploitative by today's standards, at the time male and female nudity appears to have been more acceptable than we might expect, so long as it was framed by suitable gestures towards art or the innocence of nature. The fashion for Art Deco often celebrated the human form and there was also a well established cult of the body. During the 1920s the Mirror had occasionally published studies of the male body in classical poses, curiously homoerotic 70 years on, though female nudity was less common. The caption for this photo reads: 'Far off the beaten track, on the secluded reaches of a North Auckland river, these Māori girls pose for a moment while the camera records a beautiful and striking picture of youth.' Alfred Waterhouse's popular painting Hylas and the Nymphs may have been an inspiration; certainly the impulse to recreate the innocence of a past age is the same.

Recently Lydia Wevers described magazines as 'engines of culture', conjuring an image which for me perfectly captures their role in the 
evolution of our national identity. In this small selection of images from just one New Zealand magazine, I hope I have demonstrated the extent to which this was the case, specifically in the matter of 'Maoriland', a fiction coined in the minds of numerous editors, writers, artists, and photographers, all eager to distil from their own experience whatever was unique about these islands. The Mirror and similar publications regarded themselves as windows through which the world at large might be shown 'Maoriland', encouraged to visit by images of the exotic and picturesque. The bane of an entire generation of writers and artists, many of whom were stimulated to re-create and modify anew the fiction that is New Zealand, in political terms 'Maoriland' may be read as the expression of a discourse which made invisible or otherwise nullified the position of Mãori as a colonised people. $\infty$
STEPHEN HAMILTON is a freelance historian and editor. He has a PhD in English from the University of Auckland and has published articles on New Zealand literary culture. A member of the Steering Committee of the History of Print Culture Project, he is currently writing a history of the little magazine in New Zealand, funded by a New Zealand History Research Trust Fund Award. An earlier version of the present article was delivered at the Stout Research Centre on 10 September 1997.

\title{
NOTES
}

1 Reynolds Ted, 'Liquor Baron Built Empire from Loophole', New Zealand Herald 2 October 1991, section 1,9.

2 Kelliher, H.J., New Zealand at the Cross Roads (Auckland, 1936).

3 Burnett, Ron, Cultures of Vision (Bloomington, Indiana, 1995), 75.

4 Cooper, Wiremu, 'Photography in Maori Society', Photofile Spring 1988, 4.

5 Te Awekotuku, Ngahuia, Mana Wahine Maori: Selected writings on Maori women's art, culture and politics (Auckland, 1991), 81

6 Te Awekotuku, Ngahuia, "The Sociocultural impact of tourism on the Te Arawa people of Rotorua' (PhD Thesis, University of Waikato, 1981)

7 Buck, Peter Te Rangi Hiroa, The Evolution of Maori Clothing (New Plymouth, 1926) and Vikings of the Sunrise (New York, 1938).

8 Pratt, Mary Louise, Imperial Eyes: Travel writing and transculturation (London, 1992).
9 Whitcombe and Tombs, Maori Life in New Zealand (Christchurch, c1926) and New Zealand in Pictures (Christchurch, c1926).

10 Cowan, James, Travel in New Zealand (Christchurch, 1926).

11 Waaka, Peter, 'Mita Taupopoki', Dictionary of New Zealand Biography (Wellington, 1990), 505-507.

12 Pratt, Imperial Eyes, 7.

13 Ibid.

\section{FAREWELL COLONIALISM The New Zealand International Exhibition, Christchurch 1906-07}

\author{
Edited by \\ JOHN MANSFIELD THOMSON
}

$\mathrm{T}$ HIS ATTRACTIVELY ILLUSTRATED NEW BOOK is a testimony of a memorable occasion and an inspiring contribution to our social history. It recreates the atmosphere and spirit of the Exhibition, from Joseph Maddison's white and gold building, to the gardens surrounding it, the impressive Maori $\mathrm{Pa}$, which also hosted visitors from the Pacific Islands, to the comprehensive exhibits of the British Government, Canada and the Australian states. Economic, political and social aspects are discussed, as well as the visual arts and music. Perhaps the most poignant contributions are those of the Maori visitors, given here in the original language and in translation by Margaret Orbell.

176 pp, $173 \times 245$, with over 100 illustrations, some in colour. ISBN 0864693184 . Copies can be purchased from Dymocks and other bookshops or may be ordered from the Dunmore Press, Freepost 105373, PO Box 5115, Palmerston North, at \$39.95 (incl. p\&p).

\section{CONTRIBUTORS}

$\therefore$ Ann Calhoun

$\therefore$ Walter Cook

$\therefore$ Bernard Kernot

$\therefore$ John E Martin

$\therefore$ Gavin Mclean

$\therefore$ Margaret orbell

$\therefore$ Jock Phillips

$\therefore$ Peter Shaw

$\therefore$ Joln Mansfield Thomson

$\therefore$ Linda Iyler

a Jane vial 